\title{
Taxonomical Study of Family Buprestidae (Coleoptera) in Aljabal Al Akhader, Libya
}

\author{
Hedaya H. Karam 1: A. K. Mourad' ${ }^{2}$; H. A. Mesbah' ${ }^{2}$ and Y. M. Z. Yahiya ${ }^{3}$
}

\begin{abstract}
Taxonomical study was carried out on Family Buprestidae at Al-Jabal Al-Akhder district (Libya) from July 2007 to October 2009. Ten species of the family were collected and classified into five subfamilies. Three species are belonging to the genus Julodis of Subfamily Julodinae, one of these species has three subspecies. Two species of subfamily Polycestinae both are belonging to the genus Acmaeodera. Each of the subfamilies Chrysochorinae, Buprestinae and Agrilinae are represented by only one genus with only one species. .Keys to the studied subfamilies, genera of each subfamily and to the species of each genus are constructed. All the studied species are described in detail, with demonstrated photos and the taxonomical characters are illustrated. Anthaxia kneuckeri and Capnodis exice are first recorded in Libya in the present study.
\end{abstract}

\section{INTRODUCTION}

Family Buprestidae is an essentially tropical large family comprising approximately 400 genera and over 15,000 species (Gilloff, 2005). All species are plant feeders. The adults may be found on flowers, where they probably take nectar, or on foliage, especially of the larval host plant, where they may feed on the leaves. The larvae feed in living or dead plants, under the bark or in the wood of trees and shrubs, in twigs, stems of herbaceous plants, roots of trees, shrubs or perennial herbs, or as leaf miners. The larvae which feed on hard material pupate within the food plant, while leaf miners pupate in the soil. Adult buprestids are strong fliers, and can disperse over considerable distances in search of hosts. In general, buprestids tend to attack plants which are already damaged, injured, or physiologically stressed for example by drought or nutrient deficiency. Few species seem to attack apparently healthy plants. The higher classification of the family is not yet settled. The number of subfamilies recognized varying from five to thirteen depending on the author (Booth et al.,1990). Cobos (1980) divided the family into thirteen subfamilies, and his system was followed by Nelson (1981) who provided keys to the eleven subfamilies which occur in North America. Kerremans (1902-1903) provided keys to the world genera, and a catalogue of Egyptian buprestidae (1908). His monograph to the
World fauna (Kerremans, 1904-1914) was incomplete. Faunal works with keys to genera and species include those by Fisher (1925) for the West Indies, Théry (1928 \& 1930) for North Africa and Théry (1929) in Egypt. Alfieri (1976) listed 177 buprested species in his monograph of coleoptera in Egypt.

In Libya coleopteran insects collected by scientific expeditions, including family Buprestidae, have been listed in some literature (Zavattari, 1934; Peyerimhoff, 1948 and Damiano, 1961). These previous works were not supplied with a detailed taxonomical description, therefore, the present work aimed to study the buprestid beetles in Al-Jabal Al-Akhadar district (Libya) from the taxonomical point of veiw.

\section{MATERIALS AND METHODS}

The present investigation was carried out to survey certain common buprested insects at Al-Jabal Al-Akhder governorate (Libya) from July 2007 to October 2009. This is an evergreen forest, the highest recorded trees in this area is Junipers phaenica (Cupressaceae) and represents $80 \%$ of the total trees, followed by Arbutus pavarii(Ericaceae),Pistacia tentiscus (Anacardiaceae) and Olea europea(Oleaceae), in addition to other trees and shrubs.

The collecting methods of the wood borers were:

1. Light traps fitted with 250 watt bulbs, were fixed on the ground or hanged near the plants.

2. Cloth traps by using a white cloth provided with a light source of 500 watt bulb to attract insects then collected by hand or forceps.

3- Shaking the infested plants and receiving the dropped insects on a white sheet spread under the tree.

4- Preserving the branches infested with wood borers in cartoon boxes until the emergence of adult beetles.

Collected insects were identified with the help of stereoscopic binocular microscope. The taxonomical keys of Britton (1979), Borroer et al. (1989) and Booth et al. (1990) were used for the determination of the family. Also, keys adopted by Moussa (1977) and Mohamed (1990) were used for identification of the genera and species.

\footnotetext{
${ }^{1}$ Dept. of Applied Entomology, Fac .of Agric. Alex. Univ.

${ }^{2}$ Dept. of Plant Protection, Fac.of Agric. Saba Bacha, Alex. Univ.

${ }^{3}$ Dept. of Zoology, Fac. Of Science, Qubba branch,

Omar El-Mokhatar - Univ. Libya

Received October 28, 2010, Accepted November 28, 2010.
} 


\section{RESULTS AND DISCUSSION}

\section{Characters of family Buprestidae:}

Although the members of family Buprestidae are very variable in size and shape, they have a very characteristic form, being rigid, very heavily sclerotized, and frequently brilliant metallic in colouration, hence their common name of jewel beetles or metallic woodboring beetles. Body elongate oval in shape, $1.5-100$ $\mathrm{mm}$ in length.

Antennae 11-segmented, short and serrate, pectinate or flabellate, serrated portions of segments with either diffuse or discrete areas of sensory pores. Head more or less hypognathous, deeply sunk in prothorax, frons often excavated or strongly sculptured. Eyes oval to elongate, entire. Pronotum usually closely fitting to elytra, its outline often continuous with that of elytra, side margins mostly distinct at base, but sometimes becoming evanescent or rounded anteriorly. Scutellum small to well developed, or completely hidden beneath elytra. Elytra variable from elongate, parallel sided, or tapering strongly in posterior half, to short and subconical, convex or flattened on disc. Upper surface glabrous or with short pubescence, sometimes forming patterns. Prosternum usually long in front of procoxae, with prosternal process produced and often dilated behind procoxae, received into channel in meso- and/or metasternum. Procoxae globular, their cavities open behind. Metasternum with distinct transverse suture (Fig.2A). Metacoxae strongly excavated to receive metafemora(Fig.2A). Abdomen with five visible sternites, basal two fused, often with suture partly obliterated(Fig.2A), abdominal tergites heavily sclerotized and usually brightly coloured. Legs relatively short, tarsal formula 5-5-5, at least segment 4 lobed beneath (Booth et al.1990).

\section{Proposed key to subfamilies under study}

1. Body large, robust, convex, more than $20 \mathrm{~mm}$ ......................... 2

1'- Body small, elongate, moderately flattened, less than $20 \mathrm{~mm}$ .3

2(1) Front rectangle, does not contract by antennal insertion (Fig.2B), prosternal process narrow ; eyes rounded; elytra obtusely tapering in posterior half......................Julodinae.

2'- Front contracted by antennal insertion (Fig.2C); prosternal process wide; eyes elongate; elytra sharply tapering in posterior half.....................Chrysochorinae $=$ Chalcophorinae.

3(1') Scutellum indistinct; sternal cavity for reception of prosternal process formed entirely by mesosternum; posterior part of elytra toothed marginally.................. Polycestinae.
3'- Scutellum distinct; sternal cavity only partly formed by mesosternum; posterior part of elytra not toothed marginally.... 4

4(3') Posterior margin of pronotum straight; base of elytra slightly depressed; hind coxal plates distinctly dilated medially.......... Buprestinae.

4'- Posterior margin of pronotum sinuate; base of elytra strongly depressed; hind coxal plates not such dilated....................Agrilinae.

\section{A- Subfamily: Julodinae}

\section{A- 1- Genus: Julodis Eschscholtz,}

The genus Julodis belongs to subfamily Julodinae was the only collected genus. This genus was represented in the present study by three species, of which one has three subspecies. These beetles are identical in the following general characters:

Body robust, broad oval, elongate and convex, from 28 to $35 \mathrm{~mm}$. in length. Head plane or slightly concave; epistome sinuate or notched, labrum present, eyes rounded, little prominent .Antennal socket raised at inner side forming a blunt dent. Antenna short, $1^{\text {st }}$ segment arched, clubbed, $2^{\text {nd }}$ one short, $3^{\text {rd }}$ one elongate, depressed or subcylindrical, $4^{\text {th }}$ segment shorter, 5-10 transverse, triangular, serrate at internal side, $11^{\text {th }}$ one truncate or notched,(Fig.2D). The last 7 segments covered on their both sides with diffused pores and coated with a silky pubescence.

Pronotum transverse, convex, retracted backwards, sides rounded and depressed medially at base in front of elytra suture, base bisinuate with a narrow and sharp median lobe(Fig.2E); scutellum absent; elytra elongate, lateral sides emarginated, attenuate in rounded point at apex, not dented at extremity. Prosternum narrow, carinated, with narrow posterior process extend in a groove in anterior part of mesosternum. Tarsi wide and depressed, the 4 first segments subequal, each with a large pad ventrally, $5^{\text {th }}$ one squared, claws lobed at base. Abdomen 5 segmented, pubescent, coarsely punctuate. Last segment narrowed posteriorly.

The species under study are different in colour, the length of pubescent covering the body and its arrangement, presence of pronotal carina and the degree of body wrinkles.

\section{A-1-1-Julodis fimbriata klug(Fig 1A)= Julodis arabica Gory.}

Body $35 \mathrm{~mm}$. in length and $13 \mathrm{~mm}$ in width. Colour bronzy green with reddish luster at the posterior half of elytra and ventral side. Head carina fine and smooth. Pronotal carina on the anterior third only. Dorsum covered with dense short whitish pubescent. Elytra roughly wrinkled at base. Each elytron with four 
longitudinal ridges and fine pubescent spots between them, the spots on lateral and sutural sides large, forming interrupted bands. At the base of elytra pubescent gathered to form two distinct whitish spots.

\section{A-1- 2- Julodis aequinoctialis kerimi Fairmaire (Fig} 1B).

Body $30 \mathrm{~mm}$. in length and $8 \mathrm{~mm}$. in width. Colour metallic green coppery with densely white pubescence, hairs on ventral side long. Head with fine short carina. Pronotum without carina. Each elytron with five villous impressions forming longitudinal bands and short one around basal part of elytral suture. Intervals between these longitudinal bands with very fine paired bands. Basal part of elytra humped around suture.

\section{A-1- 3- Julodis aequinoctialis harterti They (Fig 1C).}

Body $29 \mathrm{~mm}$. in length and $12 \mathrm{~mm}$. in width. Colour metallic green, ventral side reddish. Wrinkles on dorsum very fine, except at base of elytra. Pubescence long distributed allover dorsal side and form lateral interrupted band on each elytron and another two short ones at base. Head with longitudinal carina with two lateral short branches medially. Pronotum strongly impressed at middle of base, with fine smooth carina.

\section{A-1- 4-Julodis aequinoctialis lucasi Saunder (Fig 1D).}

Body $28 \mathrm{~mm}$. in length and $10 \mathrm{~mm}$. in width. Colour bronzy greenish blue, ventral side red with fine transverse blue line at the end of each abdominal sternum. Pubescent long, whitish in colour. Each elytron with four longitudinal rows of large spots of dense pubescence and lateral one with much smaller spots. Head carina similar to that of the preceding species. Pronotal carina short, existing on posterior part in front of basal depression. Legs furnished with long hairs.

A- 1-5-Julodis onopordi koenigi Mannerheim, (Fig 1E).

Body $28 \mathrm{~mm}$. in length, $10 \mathrm{~mm}$. in width. Colour shiny dark brown. Dorsal side strongly wrinkled especially base of elytra. This species characterized by the long, dense and whitish; erect hairs covering all the body. Depressed pits on each elytron furnished with dense pubescence forming five interrupted longitudinal bands. Prosternal process and legs covered with long hairs.

\section{B. Subfamily: Chrysochorinae}

\section{B-1- Capnodis excise Menetries (Fig 1F)}

Body robust, $35 \mathrm{~mm}$. in length and $15 \mathrm{~mm}$. in width. Colour shiny black with reddish bronzy patches, covered with whitish dense pubescence on pronotum and some patches of elytra. Head rogues, densely punctured, front depressed, with short coronal suture, antennal sockets triangular, labrum distinct and sclerotized. Antennae short (Fig. 2F), $1^{\text {st }}$ segment thick, 2-3 very short, subglobular, $4^{\text {th }}$ one elongate, following segments dented on internal side, 5-6 triangular, 7-10 transverse and perforated on their two faces partially from $6^{\text {th }}$, last segment rounded apically. Eyes elongate, slightly oblique (Fig. 2C). Pronotum (Fig. 2G) with inverted vshaped fossa in front of elytral suture, disc very rugose, with whitish pubescence in punctures and also with a characterized longitudinal smooth relief extending along midline, widened at middle, surrounded with two pairs of smooth relieves, anterior pair small and rounded, posterior pair larger and oval. Elytra pointed and truncate apically, emarginated laterally in the level of metacoxa, callus well marked, with ten striae, interstriae smooth except for some punctures in patches provided with dense pubescence. Scutellum indistinct. Legs robust; femora cylindrical, anterior ones fusiform, tibiae cylindrical, anterior carinated on their external edge; tarsi abnormally widen, their segments triangular, and deeply notched at their apex, except the last one which is elongate and rectangular; claws simple. Abdominal extremity feebly bilobed with a very small median notch in male, but rounded in female. This species is recorded for the first time in Libya in the present study and was not found before in the work of Zavattari (1934) and Damiano(1961).

\section{C-Subfamily: Polycestinae \\ C-1 .Genus: Acmaeodera Eschscholtz:}

Body mostly elongate, more or less cylindrical, mostly finely hairy. Head plane or a little convex; frons more or less depressed; epistome very short, strongly retracted at its base by the antennal cavities.Antennae (Fig. 2 I) short, slender, $1^{\text {st }}$ segment long, clubbed and arched, 2-4 subequal, pyriform, 5-10 serrate, transverse, , with obtuse or sharp dents, perforated, last segment globular. Eyes big, slightly convex and parallel.

Pronotum transverse, rarely longer than wide, sometimes wider than elytra, sides rounded, base truncate, straight and finely striated in its whole length; disk depressed, grooved or convex. Elytra fused, variable in form, rounded or acuminate at apex, denticulate on posterior edge. Prosternum wide, plane or slightly convex, widely rounded at apex; mesosternum entire, notched onwards by reception of prosternal lobe; meso-metasternal suture straight, often little distinct; legs short; slender; tarsi little robust, their $5^{\text {th }}$ segments nearly as long as preceding segments together; claws dented or lobed. 
A

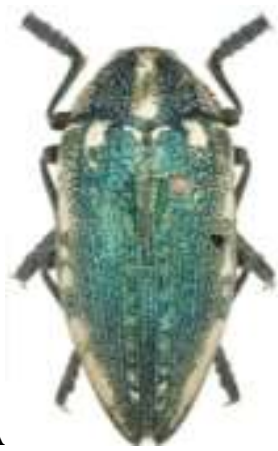

$\mathrm{D}$

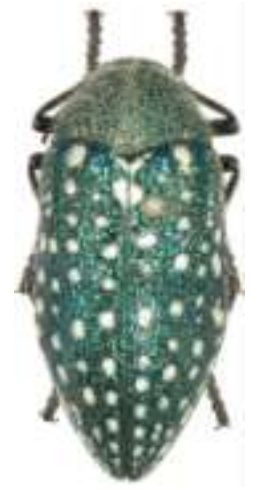

G

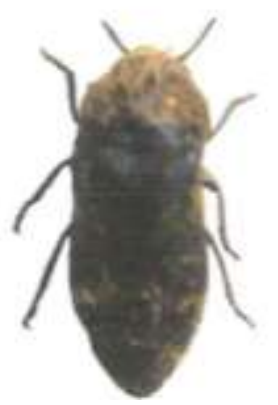

$\mathrm{E}$

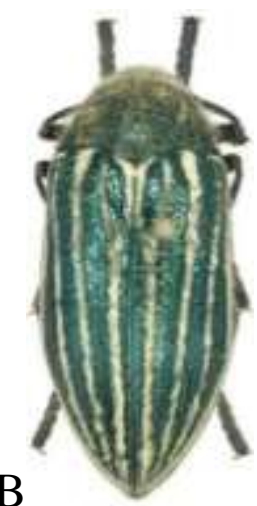

B

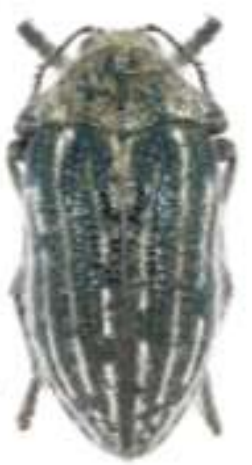

$\mathrm{H}$
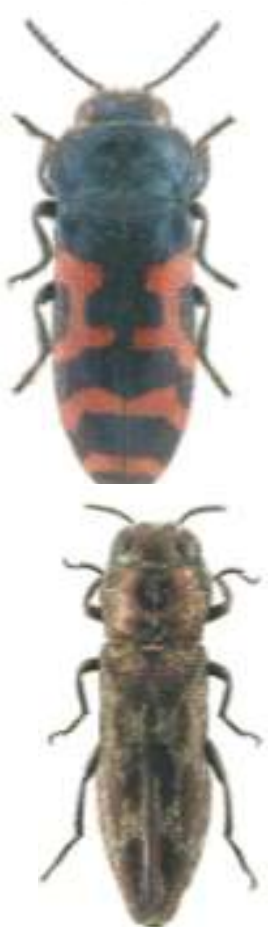

F- Capnodis excise (35mm.)

G- Acmaeodera lanuginose $(6 \mathrm{~mm}$.)

H- Acmaeodera ottomana $(7 \mathrm{~mm}$.)

I- Anthaxia kneuckeri(6mm.)

J-Agrilus lituratus ( $3 \mathrm{~mm}$.)

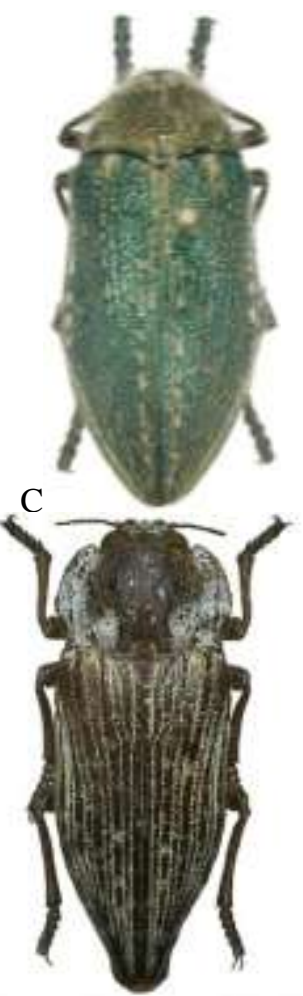

I

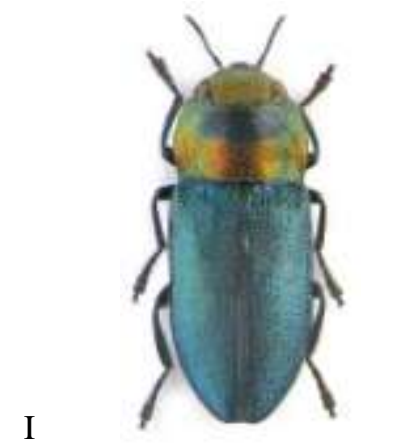

F
A- Julodis fimbriata $(35 \mathrm{~mm}$.)

B- Julodis acquinoctialis kerimi (30 $\mathrm{mm}$.)

C- Julodis acquinoctialis harterti $(29 \mathrm{~mm}$.)

D- Julodis acquinoctialis lucasi $(28 \mathrm{~mm}$.)

E- Julodis onopordi koenigi $(28 \mathrm{~mm}$.) 


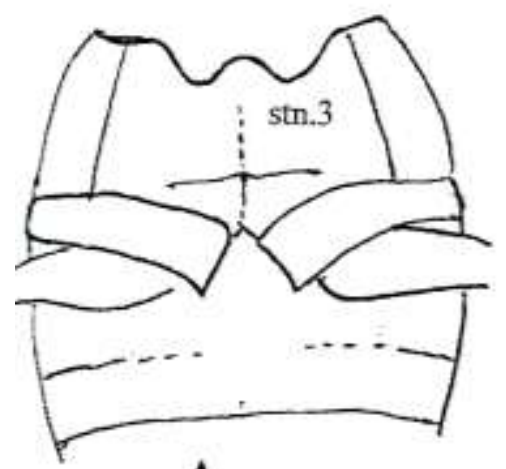

A

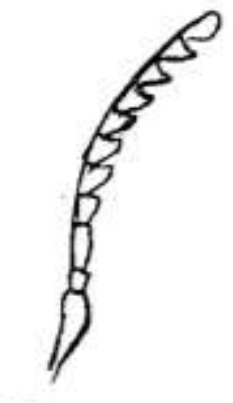

D

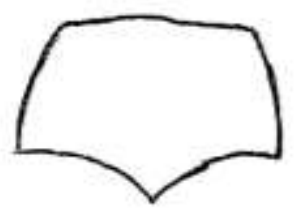

E

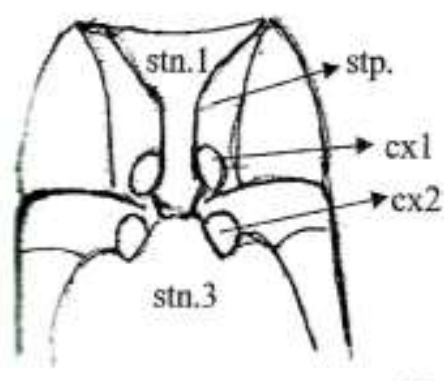

$\mathrm{H} \quad \mathrm{I}$

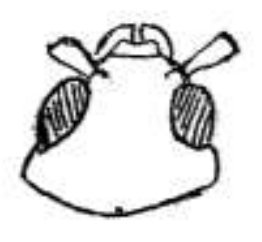

B

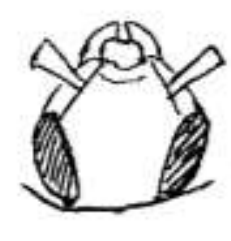

C

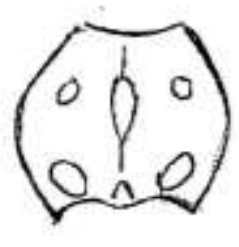

G

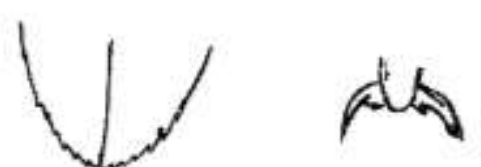

J

Figure 2 .

A- Metasternum and two basal abdominal sternites of fam. Buprestidae.

B- Head of subfamily. Julodinae.

C- Head of subfamily. Chrysochorinae.

D- Antenna of genus Julodis.

E- Pronotum of genus Julodis.

F- Antenna of Capnodis excisa.

G- Pronotum of C. excisa showing the smooth areas.

$\mathrm{H}$ - Thoracic sterna of $C$. excisa showing prosternal process (stp.); $\mathrm{cx}_{1}$ : procoxal cavity . $\mathrm{cx}_{2}$ : mesocoxal cavity.

I- Antenna of Acmaeodera lanuginose.

$\mathrm{J}$ - Apex of elytra of A. lanuginose

$\mathrm{K}$ - Claw of A. lanuginose 


\section{C-1-1- Acmaeodera lanuginose Gyllenhal (Fig.1G).}

Body about $6 \mathrm{~mm}$. in length and $3 \mathrm{~mm}$. in width, colour shiny black. Body covered with long yellowish hairs. Head furnished with dense yellow hairs. Pronotum concave anteriorly, straight at base, disc with fine punctures and clothed with long yellow hairs. Scutellum indistinct, a deep depression exists in its place. Elytra as wide as pronotum, humeral callus raised, lateral sides notched below shoulders, striation punctured, interstriae furnished with long yellow hairs, apices rounded and finely toothed (Fig. $2 \mathrm{~J}$ ); ventral side and legs finely punctured, provided with long hairs. Claws with basal dent (Fig. 2K).

\section{C-1-2-Acmaeodera ottomana Frivaldszky (Fig.1H).}

This species resemble the previous one, but differ in having much shorter hairs covering body, each elytron with red transverse $\mathrm{H}$-shaped band at base and two horizontal bands at distal half alternate with black bands, sides of elytra not emarginated. Prothorax narrowed and depressed posteriorly. Punctures of body more rough.

\section{D-Subfamily Buprestinae}

\section{D-1-Anthaxia kneuckeri Obenberger (Fig.1I)}

Body elongate oval, finely punctured ;about $6 \mathrm{~mm}$. in length and $1.5 \mathrm{~mm}$. in width. Colour coppery red and elytra shiny olive green.Front rectangular, flat, with white hairs. Eyes prominent, elongate subparallel with straight internal border. Antennal sockets small, rounded and situated nearer to epistoma than to eyes. First segment of antenna elongate, clubbed, 2-3 short, third longer than second, 4-10 triangular and eleventh segment rounded apically. Pronotum transverse, anterior margin bisinuate, posterior margin straight, sides rounded, narrowed posteriorly. Scutellum bronzy red, subpentagonal. Elytra truncate at base, flat, humeral callus prominent, with oblique depression behind them. Posterior half acuminate and finely toothed at lateral edges. First and second abdominal segments fused and last one narrow. Ventral side and legs coppery red, coarsely reticulated. According to the revision of the of buprestid beetles lists in Libya presented by Zavattari (1934) and Damiano(1961), this species was not recorded, so this in the first record, therefore A.kneuckeri is recorded for the first time in Libya in the present study.

\section{E-Subfamily Agrilinae \\ E-1- Agrilus lituratus Klug 1829}

Body narrow, elongate, about $3 \mathrm{~mm}$. in length, 1 $\mathrm{mm}$. in width, colour bronzy black with greenish reflection. Body densely punctured. Vertex medially depressed, front flat, eyes large, kidney shaped. Antennal last 6 segments with white patch of pubescent at apex of each segment.

Pronotum narrowed posteriorly, with posterior median longitudinal depression and shorter lateral ones, posterior margin lobed with acute hind angles. Scutellum triangular, pointed posteriorly, transversely carinated, and almost divided by this carina into 2 parts. The anterior one forms a very large and little elevated parallelogram. Elytra elongate, sinuate at base, humeral callus prominent, sides sinuous and leaving lateral portion of 2 first abdominal segments visible. Apices of elytra distinctly narrow and finely toothed.

Ventral side and legs punctured. First abdominal suture obscure, claw with small basal dent legs slender; femora fusiform, often more swollen in male than in female; tibiae slender and subcylindrical, posterior ones often ciliated or lobed.

\section{AKNOELEDMENT}

Sincere thanks to Dr. Hanan M. Ramadan, associate professor of Entomology, Faculty of Agriculture, Alexandria University for her help in preparing the manuscript.

\section{REFERENCES}

Alfieri, A. (1976). The Coleoptera of Egypt, Mem. Soc. Ent. Egypt, Vol. 50:361 pp.

Booth,R.G ;M.L.Cox and R.B. Madge (1990).IIE guides to insects of importance to Man.3Coleoptera.Internationl Institute of Entomology.(An Institute of C.A.B International).The Natural History Museum.

Borror, D.J.; C.A.Triplehorn and N.F.Johnson (1989). An introduction to the study of insects, Holt, Rinehart and Winston, N.Y., 875.

Britton,E.B.(1979). Coleoptera.Chapter 30 in: The insects of Australia, CSIRO, Melbourne University Press: pp 495621.

Cobos,A.(1980).Ensayo sobre los generos de la subfamilia Polycestinae (Coleoptera:Buprestidae) (Part 1, 1978).Eos 54:15-94.

Damiano,C.P.(1961).Elenco delle specie di insetti dannosi ricordati per la Libia fino al 1960.Tibografia del governo. Nazirato dell Agricoltura,Tripoli.:27-68.

Fisher,W.S.(1925).A revision of the West Indian Coleoptera of the Family Buprestidae.Proceedings of the United States National Museum,65(9):1-207.

Gilloff, C. (2005).Entomology, $3^{\text {rd }}$ edition, springer 834PP.

Kerremans, C. (1902-1903). Coleoptera Serricornia Fam. Buprestidae. Wytsman's Genera Insectorum 12,1-338.

Kerremans, CH.(1908).Catalogue raisonne des Buprestides de l'Egypte.Bull. Soc.Ent.Egypte, I(1):84-111. 
Kerremans, C. (1904-1914). Monographiedes Buprestides. Volumes I-VII (incomplete).Bruxelles.

Mohamed, H. H. F (1990) Taxonomy and ecological studies on the family Buprestidae (Coleoptera) in Egypt. Ph.D.Thesis, Fac.Science.Ain shams.Univ.297 pp.

Moussa, M. E. (1977) Studies on wood-boring insects Ph. D. Thesis Fac. Agric. Univ. Alexandria.

Nelson,G.H.(1981).A new tribe, genus and species of North American Buprestidae with consideration of subfamilial and tribal categories. The Coleopterists Bulletin 35(4):431450 .
Peyerimhoff, P. (1948).Mission scientifique du Fezzan (19441945).V.Insectes, Coleopteres.Memoires de l'Institut des Recherches Sahariennes,Alger:84pp.

Thery,A.(1928).Etudes sur les Buprestidae de l'Afrique du Nord.Memoires de la Societe des Sciences Naturelles du Maroc19:1-586.

Thery,A.(1929).Description de Buprestides nouveau de la faune Egyptienne et remarques synonymiques. Bull. Soc.Ent.Egypte, $13: 111-145$.

Thery,A.(1930).Etudes sur les Buprestides de l' Afrique du Nord. Memoires de la Socete des Science Naturelles du Maroc, 19: 1-586.

Zavattari,E.(1934).Prodromo della Fauna della Libia. Cooperativa, Pavia:VIII+ 1234P. 


\section{الملخص العربي}

\section{دراسات تقسيمية لفصيلة الحفارات معدنية اللون (غمدية الاجنحة) بمنطقة الجبل الأخضر بليبيا}

$$
\text { هداية حمزة كرم، احمد كمال مراد، حسن مصباح، يوسف موسى زايد }
$$

فصائلChrysochorinae, Buprestinae, Agrilinae ويتبع كل

منهم نوع واحد. وقد اعدت مفاتيح تقسيمية لتمييز تحت الفصائل والاجناس و والانواع وكذلك تم اعداد وصفا كاملا للانواع موضع

Anthaxia الدراسة موضحا بالصور والرسومات. وقد سجل النوعان واندان kneuckeri, Capnodis exice
أجريت هذه الدراسة خلال الفترة من شهر يوليو 2007 إلى

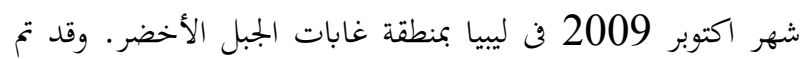

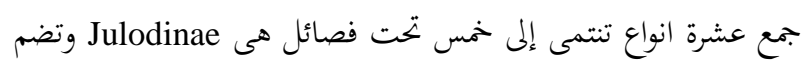
خمسة أنواع تتبع جميعا جنس Julodis وتحت فصيلة Polycestinae

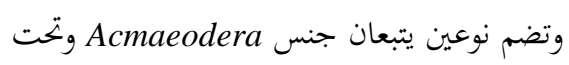

